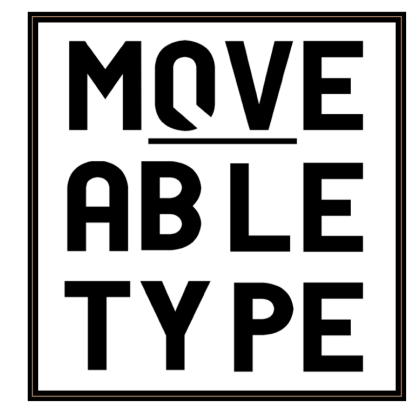

Days Without End by Sebastian Barry and The Sparsholt Affair by Alan Hollinghurst [Joint review]

Author[s]: Alex Hewitt

Source: MoveableType, Vol.10, 'Peripheries' (2018)

DOI: $10.14324 / 111.1755-4527.088$

MoveableType is a Graduate, Peer-Reviewed Journal based in the Department of English at UCL.

(C) Alex Hewitt 2018 COPYRIGHT. This is an Open Access article distributed under the terms of the Creative Commons Attribution License (CC-BY)

4.0https://creativecommons.org/licenses/by/4.0/, which permits unrestricted use, distribution, and reproduction in any medium, provided the original author and source are credited. 


\title{
RUEER HISTORIES
}

\section{ALEX HEWITT}

\author{
Days Without End. \\ Sebastian Barry. 2016. 272p. f8.99. \\ Faber and Faber. ISBN 978-0571277001 \\ The Sparsholt Affair. \\ Alan Hollinghurst. 2017. 464p. £15.99. \\ Picador. ISBN 978-1447208211
}

Gay men have always had a slightly vexed relationship to history, and any effort to write historical gay fiction is inevitably forced to navigate an endlessly complicated slipstream of nostalgia, shame, homophobia, erasure, anachronism, and violence. Both Sebastian Barry and Alan Hollinghurst are, in very different ways, largely historical writers, and both wrestle with queer life's exclusion to the historical peripheries in their most recent work. Where Barry's Days Without End (2016) affirms the actuality of queer lives in the central events of America's creation and, in so doing, interrogates the grander historical narratives that erase such lives, Hollinghurst's The Sparsholt Affair (2017) explores the subversive potential of narrating from the periphery.

The Sparsholt Affair bears marked similarities to Hollinghurst's previous novel, The Stranger's Child (2011). Once again, the novel is an episodic narrative that depicts a wide swathe of history, from 1940s Oxford to present-day London, in which the major events occur off-page; in this case the titular affair, the scandalous repercussions of which are felt but never depicted. An event and a character that would serve as the tragic centre-piece in a more conventional novel, David Sparsholt's sexual transgressions - 'a dim nexus of provisional misconduct' that becomes a 'national scandal' - remains an occluded shadow that haunts but never possesses the narrative, which is concerned with subtler, and ultimately more affecting, elements of gay life and history (182).

The novel's gaps, and the stark jumps in time that accompany them, can be somewhat disgruntling, especially the jump following the novel's brilliantly evocative opening, which casts a lengthy shadow from which the subsequent sections struggle to break free. 'A New Man', the novel's opening segment, is presented as a fragment from the 'little memoir' of Freddie Green during his time in 1940s Oxford (3). It details the impact of David Sparsholt's arrival on a group of sexually ambiguous undergraduates whose literary 'Club' exerts a heavy presence on the rest of the novel. 
As always, Hollinghurst's prose is impeccable. Freddie Green's narration veers between pastiche, parody, and straight-faced replication of the grandly repressed queers in a loving recreation of the archly euphemistic and allusive styles of Henry James, E. M. Forster, and Evelyn Waugh. There is something wonderfully fussy in the section's selfconscious literariness, and war-gripped Oxford is brilliantly depicted in all its gritty twilight; a half-empty city of 'brief dislocated intimacies' and shadowed voyeurism conducted in 'that brief time between sunset and the blackout when you could see into other people's rooms' $(43,4)$.

Much like The Stranger's Child, an inevitable sadness evolves when the novel leaves the dreaming spires and the subsequent and successive re-orientations of time and place carry a frustrating edge. Yet, where its predecessor suffered from disjointed and confusing changes of perspective, The Sparsholt Affair largely limits its focus to Johnny Sparsholt who, after Freddie Green's opening narration, becomes the novel's central character and focal point. A wonderfully sketched figure, whose work as a portrait artist provides valuable parallels to Hollinghurst's own captivating portraiture, the novel coalesces around his warm-hearted and tender perspective.

Hollinghurst has always struggled to convey juvenile characters convincingly; his depiction of William Beckwith's nephew, Rupert, in The Swimming-Pool Library (1988) was embarrassingly garbled. Similarly, the initial narrative of Johnny Sparsholt's life, which alludes to yet occludes his father's affair during the Sparsholt family holiday to Cornwall of 1965, pales in comparison to Freddie Green's poignant and evocative recollections, which might perhaps be the point. Yet the somewhat shaky and obtuse style of 'The Lookout', which is both adolescent and frustratingly repetitive in its detailing of Johnny's repeatedly frustrated adolescent infatuation, gradually develops and settles in the later segments' detailed depictions of gay London; the area in which Hollinghurst is at his most assured.

'Small Oils', 'Losses', and 'Consolations' track Johnny as he navigates the complicated legacy of his father who, like the affair that bears his name, remains always just beyond the novel's reach. In this gentle eschewing of sensationalism, Hollinghurst refuses to simplify the intricate emotional lives of gay men to the scandalous stereotyping of newspaper headlines and, in its detailing of Johnny Sparsholt's affairs in love and the creation of his own family, the novel offers a peripheral but affecting alternative to grander historical narratives.

The 1967 Sexual Offences Act provides a crucial hinge in The Sparsholt Affair's narrative; yet while he is marked by 'the irreducible fact that Johnny was doing openly 
what for David had been a matter of secrecy and then of very public shame', Johnny's life, in all its confused brilliance, becomes a powerful testament to those that live under and around the burden of previous generations (371). This culminates in what might be the most brilliant passage Hollinghurst has ever written; a hilarious and heart-breaking episode that follows a drug-addled and confused Johnny navigating the perplexing landscape of 21 st century gay clubbing and online dating.

While the novel's episodic structure contains inherent flaws - the time-jumps are uncomfortably disorientating and the first twenty pages of each segment inevitably descends into a scrambled search for clues - it proves the perfect format through which to explore Hollinghurst's great theme: the generational divides between gay men. As each segment builds from, echoes, and, in some places, simply rearranges and re-narrates previous sections, Hollinghurst constructs a beautifully elegiac panorama of 20th and 21st century gay life.

In contrast to Hollinghurst's episodic and peripheral re-narration of gay history, Days Without End's more traditional narration of untraditional lives works to centralises marginalised experiences. Also somewhat elegiac in tone, Barry's novel forms another volume in his continuing chronicle of the McNulty family history; a history that here extends beyond Ireland across the Atlantic and to unconventional understandings of the family.

The story follows Thomas McNulty and his lover John Cole through an America in the process of its own making and depicts the tangled process by which, as McNulty escapes the violence of the Old World, he becomes complicit in the foundational violence of the New. Opening in 1851 Missouri, McNulty's narration ranges from his tumultuous and violent immigration to America from a famine-stricken Ireland to his early experiences cross-dressing for miners in Daggsville with John Cole, whom he discovers by chance 'under a hedge in goddam Missouri', and then on to their enlistment in the US army (PN). The violence of both the Indian wars and the Civil Wars is rendered in startling, impressionistic prose and the pair's engagement in the atrocities of war, much like the characters' earlier forays into blackface, are uncomfortable historical realities that the novel refuses to shy away from.

Yet amidst the violence, Barry weaves shining glimpses of love and hope into his chronicling of the blood-soaked birth of modern America. In both McNulty and Cole's relationship and in their eventual adoption of Winona, a Native American girl displaced by the conflicts they participated in, Days Without End presents a makeshift family that becomes the novel's beating heart. The fragile, hidden beauty of McNulty and Cole's love 
for each other and for Winona is carefully interwoven through the bloody tangle of the novel's war narratives, revealed in fragmented but achingly tender sentences that prove, as McNulty states, 'love laughs at history a little' (91).

Barry's breathlessly lyrical book, which frequently threatens to collapse under the weight of the events it narrates and the intensity with which they are depicted, is sustained by the urgent joys and rhythms afforded by Thomas McNulty's narration. His voice, whose obvious forbearers run from Huckleberry Finn to Tom Joad, shivers and stretches across the novel's pages and proves a unifying force in a book that carelessly flits between the genres of the picaresque, the western, and the war novel.

Barry's quiet examination of queer lives amidst such masculine, militaristic violence is his real triumph. Dedicated to his gay son, Toby, Days Without End is a gorgeous celebration of alternative ways of loving and living that feels radical in its matter-of-factness. That such a thoughtful meditation is seamlessly interwoven into to the novel's compulsive and heart-rending plot, which grabs the reader early and refuses to let go even in the closing pages, is a testament to Barry's genius as a storyteller and a documenter of the human heart.

Both Johnny Sparsholt and Thomas McNulty are searching for that 'unknown realm where lovers act as lovers without concealment' and, in Hollinghurst and Barry's divergent but similarly radical imaginings of queer history and family, The Sparsholt Affair and Days Without End render that unknown realm tangibly visible and, more importantly, possible (PN). Where Hollinghurst undermines conventional, sensationalist understandings of gay history, Barry depicts gay men participating in the foundational events of America and, in the process, rearranges the conventions of history that render such lives invisible. Both Days Without End and The Sparsholt Affair look on the violent histories that haunt contemporary gay life and, through disparate engagements, give love the chance to laugh at history a little.

University College London alex.hewitt.17@ucl.ac.uk 